\title{
EDUCATION FOR CONSERVATION ${ }^{1}$ \\ BY C. GORDON O'BRIEN
}

General Secretary, Agricultural Institute of Canada, Ottawa, Canada

$\mathrm{O}$ NE OF CANADA's current problems is that of getting some overall action started to stop the large annual losses arising out of inadequate conservation and land use practices.

Until such time as the average citizen and the average politician are both convinced of the necessity for a broad and comprehensive program of soil and water conservation and land use, it is evident that progress will continue to be slow.

\section{Publicity Needed}

The task of publicizing this problem and promoting concerted action to solve it is worthy of the support of all our great public-serving institutionsthe magazines, daily and weekly papers, the radio, the banks and other organizations through their house organs, and so forth. The farm press is already doing a good job-but its effort is directed to a field which, by and large, is already aware of the need. Farm organizations, provincial and national, have repeatedly petitioned the governments to do something more than is being done about this matter.

It would appear that substantial progress cannot be made unless the literature reaching the urban population makes a deliberate effort to bring home to these people the serious consequences of continued and unchecked losses in this field.

In the last few years the urban press has missed entirely a number of good opportunities of bringing home to the public the results of poor conservation. Floods and power shortages were both treated from the standpoint of immediate inconvenience to the public, while, except in rare instances, no mention was made of the fact that these same floods and power shortages are, in many cases, the consequences of our wanton and wasteful practices in relation to the conservation of our forests and agricultural lands.

Figures for 1946 show that fire, insects and disease accounted for the loss of more wood than all of the pulp and paper industry combined. Not enough trees are being planted and not enough money is being spent on forest research. This is only one phase of the problem, but it is basic to agriculture and to industry, both of which depend on proper forest management for a continued water supply.

EVERYONE IS AFFECTED

It should not be too difficult to convince the urban dweller that this whole conservation problem is not one affecting the farmer only but, on the contrary, that it is a community problem and affects every individual in the community.

Soil conservation affects everyone! The country provides food, clothes and lumber for the city man. The lawyer, grocer, dentist, mechanic, hardware merchant and doctor all number farmers among their customers. So, they too have a big stake in seeing that these customers are on good soil. These farmers pay taxes, maintain schools, churches and roads. Where they are not

\footnotetext{
1 Reprinted from Agricultural Ingtitute Review, Jangary, 1950, by courtegy of the Agricaltural
} Institute of Canada. 
able to do this for themselves, it becomes the responsibility of the city man to help do it for them. In the ten years 1939-48, the Dominion Government gave $\$ 63,000,000.00$ to farmers in Western Canada who were impoverished through lack of crops. The dentist, lawyer and mechanic, in Eastern and Western Canada, all helped, through their taxes, to provide that money to these farm people.

Industry looks to the farm for much raw material. It also depends for much of its operation on water stored in the soil. So water conservation is important to industry as well as to the farmer, who requires it for his crop production. Fifty gallons of it is needed to produce an ear of corn; 50 gallons go into the production of a loaf of bread, and 33 thousand gallons go into the making of a ton of steel.

StaRt With THE Schools

The problem, therefore, is an educational one. Education, however, despite its power for giving to democracy its chief advantage and ability to work, has some limitations. It is slower than compulsion and, with this large and serious problem, speed of action has some importance. This is no argument for using compulsion-although Britain, following a period of education, is now using it-but it is an argument for intensifying our educational efforts, since this is the avenue whereby ultimate action will be secured under our present system.

The educational effort, of course, has a double-barrelled implication. The farmer, firstly, must be convinced that the proper conservation methods will allow him to reap additional benefits and be, therefore, persuaded to adopt these new and improved methods of soil erosion control, water conservation, soil fertility maintenance, and land use. The public, secondly, must be educated to the seriousness of the problem in order that they will give assistance and encouragement to governments to implement an overall program.

Speaking of this educational effort, Dr. H. H. Bennett, Chief of the United States Soil Conservation Service, emphasizes the importance of educating the children. He states, "We cannot be assured of the permanency of our soil conservation work until the concept of its absolute necessity sinks deeply and fixedly into our physiological make-up. The one best way to get this into our national habits is to start early in our schools, in order to plant the ideas deeply and firmly in the minds of our children. We must get it into our very bloodstream, so that soil conservation-so vital to national and world prosperity, happiness, and health-becomes a part of our national culture as a fixed national objective."

EVERYONe MUST HeLP

The average city person may ask, "If this question of soil conservation is a good thing for the farmer and will benefit him, why doesn't he get on with the job? Why does he require the help of governments, industry and city people?"

The simple fact is that the whole job is, in most cases, beyond the ability of the individual farmer. The problems of soil conservation involve watersheds, water rights, etc., and even the most simple conservation practice on one farm may affect a half-dozen neighbouring farms. It is, therefore, necessary to have legislation to cover action which may be taken by an individual farmer, 
or group of farmers, and action which may have to be taken by a community, county, province, etc., to integrate the working arrangement with other interested parties.

Many of the tasks require the use of heavy machinery and the use of such machinery is often, financially, beyond the means of the individual farmer. Yet, because this whole question is so deeply tied up with the national prosperity, it is just as much in the interests of the city man to see that that particular machine is available to do that particular job on that particular farm as it is to the farmer who lives there. This is the reason why the whole problem must be treated as a "national" and not just as a "farm problem".

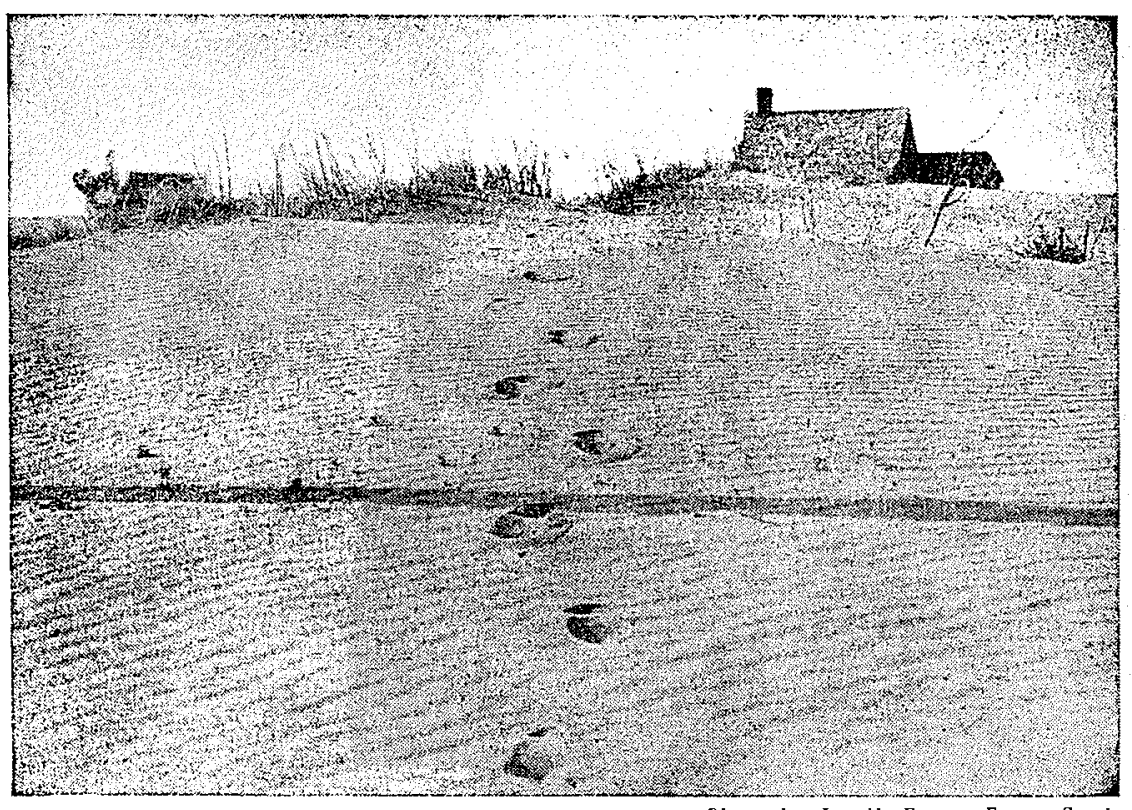

-Phoso by Lovell Exper. Farms Servic This is an extreme example of the final results of soil drifting-desolation and abandonment
of farm lands.

A Suggested Policy

After studying this question for a number of years, the Agricultural Institute of Canada has prepared a suggested national policy on soil and water conservation and land use. This was submitted to ministers of agriculture across Canada ${ }^{2}$. As a group of over 3,200 technical and professional workers in the field of agriculture, these men are convinced that this suggested policy is a sound one and that far-reaching action will not be obtained until governments give consideration to these basic principles. The Agricultural Institute of Canada therefore asks for the support of all bodies in urging governments to adopt these basic principles in the interests of more embracing soil and water conservation and land use program for this country.

2. See Agricultural Institute Review, January, 1950. 


\section{A WARNING FROM THE PAST}

History gives many examples of what happens to lands when insufficient care is given to conservation. A most interesting statement was given to the Agricultural Institute of Canada two years ago by Franklin S. Harris, President of the Utah State Agricultural College. Speaking of the dissipation of resources in various lands, he made the following remarks:

"We might go, with profit, to the valley of Mesopotamia which was the cradle of the civilization of much of the ancient world. Here we find great rivers whose waters flow out of the highlands of Turkey, Armenia, Kurdistan and Persia through the broad fertile valley and finally reach the Persian Gulf. There is the Euphrates with its main tributary, the Khabur; there is the Tigris with the Greater Zab, the Lesser Zab, and the Diwala as chief tributaries; and there is the Karum and the Karkeh all joining to make the Shatt Al-Arab which conveys their waters into the sea.

"What a sweep of history could be recalled by this valley and these rivers! What a story they could recount of the rise and fall of empires, of the development of mighty civilizations, and of their decay, of the use and abuse of the natural resources with which this area was so richly endowed, of the building of great cities and of their destruction.

"It was almost exactly a year ago that I stood on the ruins of ancient Babylon. As I gazed out from this vantage point to the north and the south, to the east and the west, toward other centres of ancient cilivizations, I could not help but think of the folly of mankind in his abuse of the resources of the earth by which he has been so richly endowed by his Creator.

"Immediately surrounding the place where I stood had been the Hanging Gardens which were one of the wonders of the ancient world. The water of the Euphrates had been used to produce bounteous harvests which sustained millions of people in this fertile area. Down the river was Ur of the Chaldee and not so far away were the plains of Shinar where Abraham dwelt. Up the river, to the northwest, was Racca, founded by Alexander the Great, and a bit farther Jerablus, centre of the ancient Hittite Kingdom. Along the Tigris to the east and north were Nineveh, capital of the Great Assyrian empire, and not far away Arbela where Alexander defeated the Persian forces of Darius and thus cleared the path for his conquest of this entire area before he returned to Babylon to meet an early death.

"As I stood on these ruins and thought of the glory of these great empires of the past, as I visualized the millions of people who had been sustained by the productivity of the land of this vast region irrigated by the waters of these ample rivers, and then when I remembered the desolation that I had recently seen in many of these places of earlier productivity, any youthful illusions I may have had about the inexhaustibility of natural resources were definitely dispelled.

"I realized, of course, that wars had been a primary cause of the destruction and abandonment of many centres of productivity, but I was also aware that wasteful practices of those who occupied the land must be charged with at least part of the desolation. The excessive cutting of timber, resulting 
in destructive floods, the erosion of land surfaces, the water-logging of the soil, the silting of canals, the accumulation of alkali, the destruction of organic matter, and the exhaustion of fertility elements all had their effect in making waste places where fertile fields once blessed the land."

\section{Canada's Problems}

Canada has major conservation problems and, of course, they differ between East and West. In Eastern Canada the problems rank as follows, in order of importance: low soil fertility; poor drainage; soil erosion; improper land use; and flood control. These are placed in this order considering the region as a whole-bearing in mind that in certain localities one or the other of these problems might become the major one.

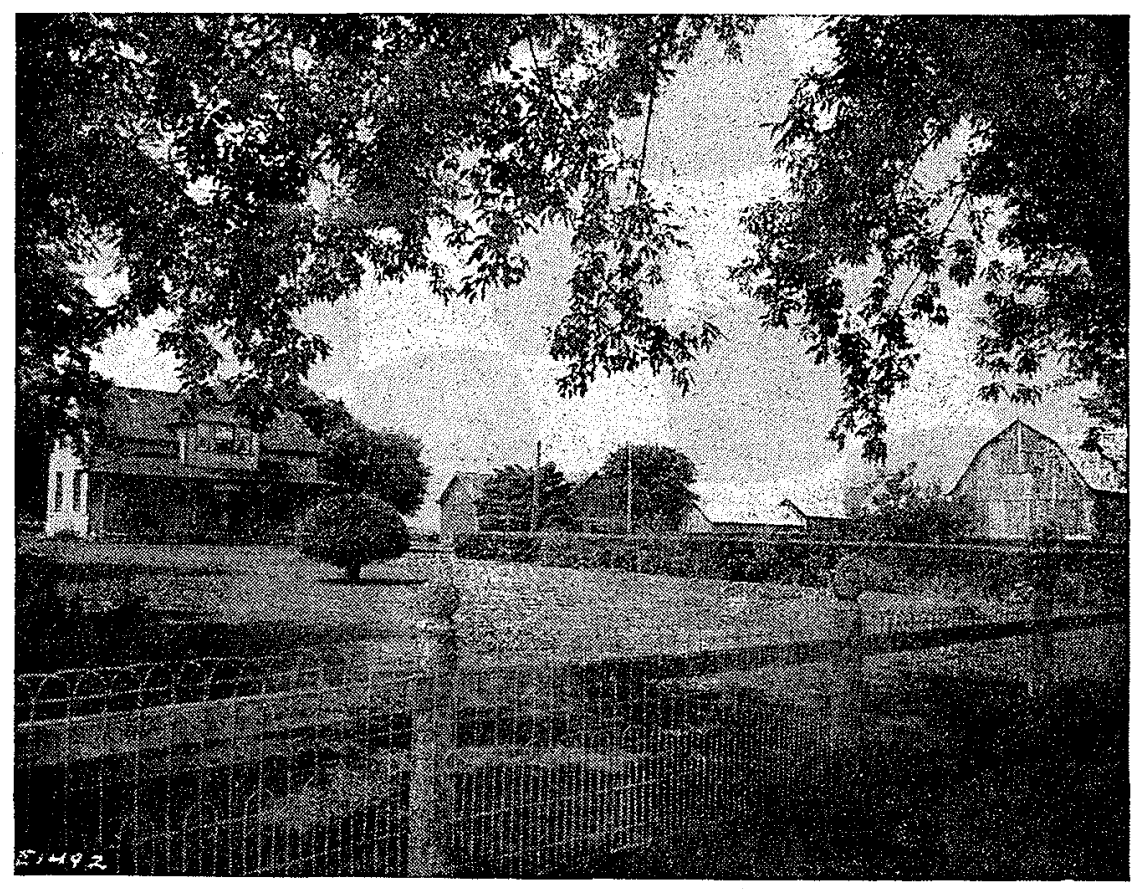

- Pholo by Lovell Exper. Farms Service

Good farming practices are reflected in the appearance of these farm buildings and surroundinge.

In the Prairie Provinces soil erosion is the main problem, followed by the improper use of land and, in some areas, soil fertility is assuming some importance.

It is sad to relate that, despite the better varities of grain that have been introduced, the larger amounts of fertilizers which have been used, and improved methods of producing crops in many ways, average yields of hay and oats have remained about stationary. The answer, of course, is that the productivity of the soil has declined. Our soil is not as good as it used to be. Contributing causes have been the lack of labour to keep weeds down and the inroads made by disease and insects. 


\section{INSUFFICIENT ACTION}

It would be a mistake, however, to assume that nothing is being done about our soil and water conservation and land use problems in Canada. A great deal is being done, but it is generally agreed that the scale of efforts is certainly not in proper relation to the need.

In Western Canada the Prairie Farm Rehabilitation Act has been functioning to good advantage and in the Maritimes the reclamation of flood lands is proceeding on a joint agreements between the Federal Government and the governments of the Provinces of Nova Scotia and New Brunswick. However, it is interesting to note that the latter is the only special assistance being given to soil conservation work in Eastern Canada and, according to the National Soil Conservation committee (as reported in an article published in this magazine in 1947), flood control ranks fifth on the list as far as urgency of need is concerned in this area.

\section{General Objectives}

Writing in the "Agricultural Institute Review" in September 1947, Dr. E. S. Hopkins, Associate Director of the Experimental Farms Service, Ottawa, and Chairman, National Soil Conservation Committee, cited the following as general objectives of a soil conservation program for Canada:

"1. The program should have permanency and should apply, as far as possible, to all parts of Canada. It should be planned so that work done by various departments would be co-ordinated.

"2. Emphasis should be placed on soil conservation problems somewhat in the order of their importance. In Eastern Canada, the main soil conservation problems are soil fertility, drainage, soil erosion, proper land use and flood control. In the Prairie Provinces they are soil drifting, water erosion, land use and, in certain soil zones, soil fertility. In British Columbia there is such a wide variation in climate and topography that any soil conservation methods would necessarily have to conform to these varied requirements.

" 3 . The soil survey should be continued and expanded in order to secure reliable and detailed information on the various soil types throughout Canada. This information, in addition to many other uses, will be helpful in land settlement and soil conservation control.

"4. An agronomic study should follow the soil survey in order to learn the soil fertility requirements and crop adaptation of the various soil types. This information would be useful in aiding the zonation of crops and in the developments of improved types of agriculture. The future may witness a much greater specialization on each main soil type and climatic zone so that each might be devoted to the type of agriculture to which it is most suited. This would enable farmers to become more familiar with the methods suitable for those specific conditions.

"5. On account of the intimate relationship between climate and agriculture, and the lack of sufficient meteorological records in Canada, a request might be made to the Meteorological Division of the Department of Transport, for the establishment of a considerably increased number of observation stations throughout Canada, particularly for precipitation and temperature records. 
"6. A plan should be developed for the best use of submarginal land in various parts of Canada. Where the climate is unsatisfactory, or where there are extensive areas of soil too unproductive for successful arable farming, they should be reforested or used for grazing. In those regions where the soil may have become impoverished through many years of poor management, or where individual farms may have been located on particularly unfavourable soil types in good farming areas, a survey might be made to locate these rundown farms. Special assistance might then be considered on what measures should be taken to improve them.

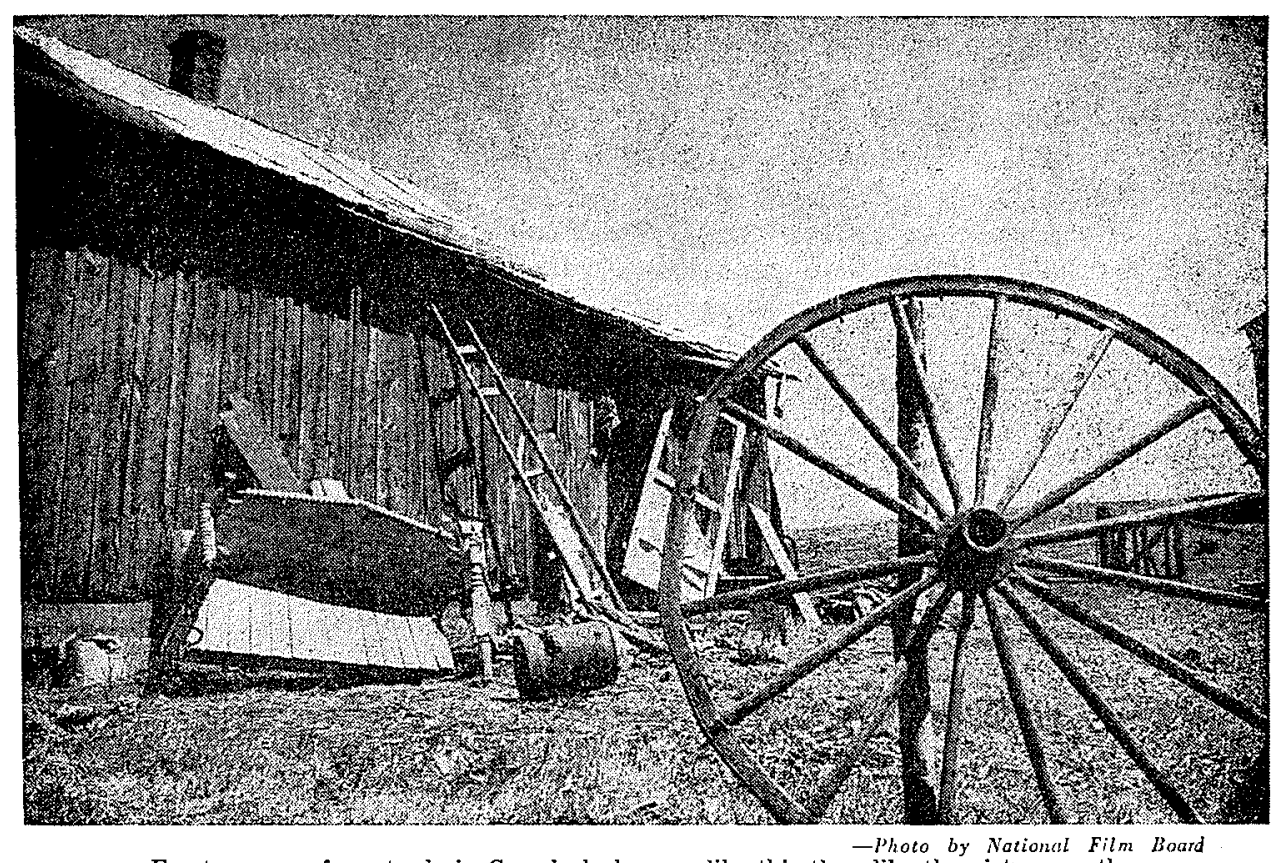

Far too many farmsteads in Canada look more like this than like the picture on the preceding page. Improper use of lnd, with ever-decreasing soil fertility, causes it.

"7. Suggestions might be prepared in regard to improved farm-lease forms applicable for various parts of Canada so that in time soil would tend to become more, rather than less, productive.

"8. As a farmer can scarcely be expected to maintain or improve his farm at his own expense for the benefit of posterity, except in so far as his neglect might damage or endanger other land, certain inducements should be offered to promote the adoption of soil conservation practices. It should include provision for technical information and for making available, if necessary at less than actual cost, any large equipment which might be required.

"9. Although irrigation is one of the most outstanding examples of how unproductive land can be made productive, a careful study is desirable on how its cost should be apportioned. 
"10. While not directly connected with the conservation of the soil, other conservation measures, such as the protection of wild animals and birds, should not be promoted at the expense of the farmer. For example, where wild birds are protected and shooting not allowed even to protect crops, recommendations in favour of the farmer would seem to be in order for a change in such laws.

"11. Where flood control affects both rural and urban property, and where conservation measures might adversely affect either of these interests, such projects should be prepared by some organization having both of these groups adequately represented.

"12. Finally, the members of the Agricultural Institute of Canada should be complimented on the active interest they have taken in the subject of soil conservation. As they have received their college education in scientific agriculture and have had many years of experience in this field, their knowledge is very helpful in developing an efficient soil conservation program. They should look forward to developing farming as a desirable and permanently profitable business in all the provinces of Canada."

These objectives are considered to be essential points in the preparation of a detailed program. The Agricultural Institute has proposed a general policy, realizing that once the general policy was accepted by governments, Canadian agricultural scientists who are well-versed in the problem are fully capable of developing a detailed program.

\section{UNIVERSAL Problems}

Conservation, of course, is a world problem. The peoples of the world are not well-fed; on the average, little land remains to be brought under cultivation, and world population is increasing at the rate of 20 million annually. During the next 25 years it is expected that the population of the United States will increase by about 30 millions. Moreover, as population goes up, there is a greater drain on the soil to provide for that population.

True, it is impossible to predict with any confidence production possibilities in the years ahead. Agricultural scientists have performed wonders in the past and no doubt can again. New advances in science may open up presently unknown avenues for increased production.

These technical and scientific advances cannot come too soon. The world, even now, is hungry!

\section{F.A.O. ACTIVE}

The Food and Agriculture Organization of the United Nations is much concerned with this problem. The following extract, which emphasizes the importance of the whole matter from a world standpoint, is the introduction to "Soil Conservation", an international study recently published by F.A.O.

"This study by the Food and Agriculture Organization of the United Nations (FAO) is a brief account of soil deterioration and some of the measures being taken in various countries of the world to correct the misuse of land. Particular emphasis is placed upon soil erosion and the conservation of soil through control of erosion, as one means of increasing and safeguarding the land resources of the world. Emphasis is placed on the physical bases of soil waste and soil conservation, but any discussion of this kind cannot ignore the 
human factor such as government and social and economic conditions that too often force land use into the ways of destruction. We may observe the spectacular physical results of soil erosion; in fact examples of deep gullies and ruined hillsides are spread over the world; we may compile statistics listing the millions or billions of ruined acres, and may bitterly condemn the farmers who ruined this land. Then we may learn by more thoughtful analysis that the fundamental trouble may have been bad government, oppressive taxation or rentals, poor education, lack of fertilizers, or simply the pressure of necessity for farmers or peasants to wrest a living from meager land resources.

"In this study much attention has been given to China and the United States of America. Both countries occupy great continental areas, with tremendous variations in climate, relief, and soils. Together they furnish ex-



- Photo by Lovell Exper. Farms Ser
Sound conservation measures would have prevented this gully erosion and resultant loss of good tillable land.

amples of land use and abuse under many combinations of physical, social, and economic conditions. At the same time, there is great contrast between the two countries in the history of land use.

"China is an ancient land as history goes, with records of agriculture going back 4,000 years or more. Pressure of population became acute in parts of the country centuries ago, and equally long ago man began his struggles with soil deterioration and with great natural catastrophes.

"The United States, on the other hand, is historically a young country, but one in which exploitation of natural resources has been savage and rapid, encouraged by the 'spirit of individual enterprise' fostered by government and popular sanction. The result has been appalling; perhaps unequalled in human history has been the speed of destruction of forests, natural pasturage for game and domestic animals, and of the soil itself. During the past fifty years move- 
ments for conservation of the forest, soil, and water resources that remained have gained momentum and there is a deflnite trend toward conservation with results almost as spectacular as the destruction had been. But much is yet to be done, particularly in control of forest fires and of soil erosion on private lands. There is still no room for complacency. So we have the two great countries as object lessons: China, with a long, long history of slow but inexorable occupation of the land; the United States, where the pressure on natural resources was dictated not so much by great need as by a restless acquisitive drive for expansion and rapid exploitation.

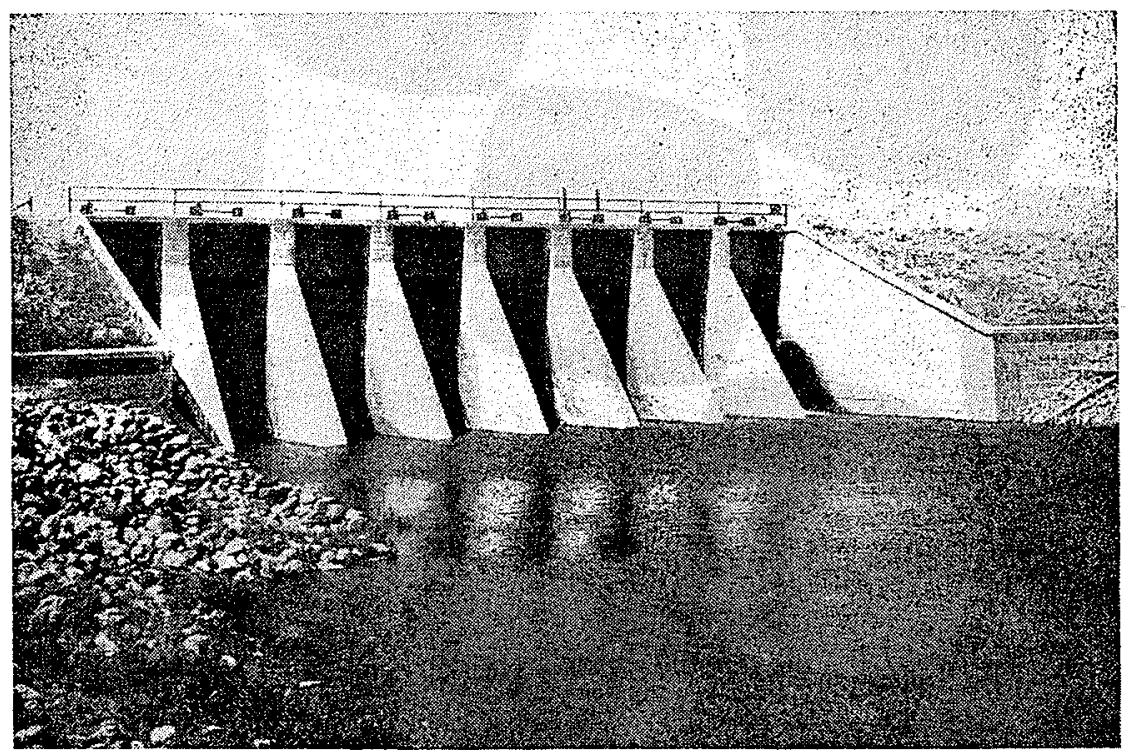

-Photo by Lovell Exper. Farms Servica

Water conservation is assisted by the construction of dams which hold back flood waters and make them available for use when needed.

"But these are only examples-the problems of soil conservation are world-wide. They are particularly acute in India, where, as in China, there is tremendous pressure of population on natural resources perhaps even more meager; in the Mediterranean region of Europe and the Near East, where centuries of human occupation and the nature of the climate and land forms have favored rapid land erosion; in Latin America, where many countries have rapidly eroding lands; and in South Africa and Australia, where conditions and problems and the history of occupation are similar to those of parts of the United States of America.

"The attention to forest lands and soils in this report is based on the stern fact that a nation cannot conserve its true cropland soils and ignore its mountains and forests. Nature accepts no such arbitrary division of the lands of the 
earth. The simple fact is that most farms are in the valleylands and plains that lie downhill from the mountains, and water runs downhill.

"Where farming depends on a flow of usable water, or is vulnerable to floods, or depends on nearby mountains for wood, it still has a vital stake in conservation of mountain forests and soils. Even in the vast Mississippi basin of the U.S.A. the frequency of disastrous floods shows clearly enough that the individual farmer has a basic concern in the mountains and forests, though his farm may be a thousand miles from them. He may adopt the most advanced system of land management on his farm, and yet be submerged and ruined by floods which come upon him from distant areas and unknown land-use pratices. One of the purposes of public policy and action is to see to it that such innocent victims are given protection.

"The relations between the farmer and mountain and forest land may be on a local and intimate scale, as where the farm touches the foot of forested hills. Or it may be that farm and forest are separated by half a continent. But the relation is the same. Good and permanent agriculture depends on good and permanent forestry. It is a dangerous, and, indeed, fatal delusion to imagine that the prime essential of land use-for food production-can survive unless government and farmer alike give jealous attention to the nonfarm lands which support or destroy farm enterprise. Nor is proper attention to forest soils of concern only to the rural economy. Cities and civilizations have deteriorated and vanished as the year-long flows of usable water without which man cannot survived first faltered and then failed, through abuse of hinterland of mountains and forests. No civilization through recorded history has been able to offset, by the most prodigious engineering works, the want of natural engineering works in forest watersheds.

"The great historical lesson of soil and water conservation is very simple: the lands of any nation or region are an indivisible unity.

"For descriptive purposes, farms, forests, and ranges may be set apart one from the other. Description and prescription for each may be elaborated. But the task of government, farmer, lumberman, and grazier is to bring observant care to each class of land, since each, under natural laws, supports and is supported by the others. This study sets forth the proposition that the care of land is a prerequisite to survival. Methods and techniques vary from farm to forest to range.

"But care must be given to each." 